\title{
Shifts in methanogenic community composition and methane fluxes along the degradation of discontinuous permafrost
}

\author{
Susanne Liebner ${ }^{1}$, Lars Ganzert ${ }^{2}$, Andrea Kiss ${ }^{1}$, Sizhong Yang ${ }^{1}$, Dirk Wagner ${ }^{1}$ and \\ Mette M. Svenning ${ }^{3 *}$ \\ ${ }^{1}$ Section of Geomicrobiology, GFZ German Research Center for Geosciences, Potsdam, Germany, ${ }^{2}$ Department of \\ Experimental Limnology, IGB Leibniz-Institute of Freshwater Ecology and Inland Fisheries, Stechlin, Germany, ${ }^{3}$ Department \\ of Arctic and Marine Biology, UiT The Arctic University of Norway, Tromsø, Norway
}

OPEN ACCESS

Edited by:

Catherine Larose,

University of Lyon, France

Reviewed by:

Marc Gregory Dumont, Max Planck Institute for Terrestrial

Microbiology, Germany

Steffen Kolb,

Friedrich Schiller University Jena,

Germany

*Correspondence:

Mette M. Svenning,

Department of Arctic and Marine

Biology, UiT The Arctic University

of Norway, Postbox 6050 Langnes,

9037 Tromsø, Norway

mette.svenning@uit.no

Specialty section: This article was submitted to

Terrestrial Microbiology,

a section of the journal

Frontiers in Microbiology

Received: 23 January 2015

Paper pending published:

11 March 2015

Accepted: 09 April 2015

Published: 12 May 2015

Citation:

Liebner S, Ganzert L, Kiss A, Yang S, Wagner D and Svenning MM (2015)

Shifts in methanogenic community

composition and methane fluxes along the degradation

of discontinuous permafrost.

Front. Microbiol. 6:356.

doi: 10.3389/fmicb.2015.00356
The response of methanogens to thawing permafrost is an important factor for the global greenhouse gas budget. We tracked methanogenic community structure, activity, and abundance along the degradation of sub-Arctic palsa peatland permafrost. We observed the development of pronounced methane production, release, and abundance of functional $(m c r A)$ methanogenic gene numbers following the transitions from permafrost (palsa) to thaw pond structures. This was associated with the establishment of a methanogenic community consisting both of hydrogenotrophic (Methanobacterium, Methanocellales), and potential acetoclastic (Methanosarcina) members and their activity. While peat bog development was not reflected in significant changes of mcrA copy numbers, potential methane production, and rates of methane release decreased. This was primarily linked to a decline of potential acetoclastic in favor of hydrogenotrophic methanogens. Although palsa peatland succession offers similarities with typical transitions from fen to bog ecosystems, the observed dynamics in methane fluxes and methanogenic communities are primarily attributed to changes within the dominant Bryophyta and Cyperaceae taxa rather than to changes in peat moss and sedge coverage, $\mathrm{pH}$ and nutrient regime. Overall, the palsa peatland methanogenic community was characterized by a few dominant operational taxonomic units (OTUs). These OTUs seem to be indicative for methanogenic species that thrive in terrestrial organic rich environments. In summary, our study shows that after an initial stage of high methane emissions following permafrost thaw, methane fluxes, and methanogenic communities establish that are typical for northern peat bogs.

Keywords: discontinuous permafrost, palsa, methane, methanogens, mcrA, peatland succession, climate change

\section{Introduction}

The sub-Arctic belongs to the regions where global climate change occurs stronger and earlier than in most other regions of the world (Serreze et al., 2000; Serreze and Francis, 2006). Associated feedbacks with the carbon cycle of the sub-Arctic are of concern considering the large amount of carbon stored in the northern high latitudes primarily in permafrost soils (Tarnocai et al., 2009). The 
carbon released to the atmosphere as greenhouse gases (GHG) is thereby an important variable for the global climate (IPCC, 2007). Since 2000, total GHG emissions have increased by on average $2.2 \%$ per year to $49 \mathrm{Gt}$ in the year 2010 (Victor et al., 2014). Thawing induced changes of the landscape occurs rapidly in sub-Arctic areas of discontinuous and sporadic permafrost (Christensen et al., 2004) such as palsas.

Palsas, frozen peat mounts, typically occur at the margin between the Arctic and sub-Arctic (Seppälä, 1986) and have been largely retreated in the circum-Arctic region since the end of the 20th century mainly as a consequence of rising precipitation (Luoto and Seppälä, 2003). Palsa retreat is thereby often associated with a total collapse of landscape surfaces in the course of less than a decade (Hofgaard, 2004). Palsa ecosystems are thus ideal field model systems to study the response of permafrost thaw upon microbial communities. Permafrost thaw is further associated with an increased release of the potent GHG methane (Schuur et al., 2008; Nauta et al., 2014). Overall, emitted methane contributes $16 \%$ to the global GHG emission (Victor et al., 2014). The formation of methane (methanogenesis) is possible at water saturation and low redox conditions and methanogenesis from $\mathrm{H}_{2} / \mathrm{CO}_{2}$ and acetate are the most common pathways in soils. Methane from $\mathrm{H}_{2} / \mathrm{CO}_{2}$ accumulates with lower rates than methane from acetate (Conrad, 1999; Metje and Frenzel, 2007). Methanogenesis includes several enzymatic steps and the last step involving methyl-coenzyme $\mathrm{M}$ is a common and conserved trait in all methanogens (Thauer, 1998). Methanogenic communities in northern peatlands have been studied with regard to dominating pathways, community structure, and temperature response. While methanogenesis in acidic peat bogs with low concentrations of mineral salts is mainly attributed to hydrogenotrophic metabolism (Bridgham et al., 2013), low temperatures, nutrient rich conditions, and permafrost environments also promote acetoclastic methanogens (Ganzert et al., 2007; Kotsyurbenko et al., 2007; Barbier et al., 2012; FrankFahle et al., 2014). Additionally, methylotrophic methanogenesis via methanol can play a substantial role in certain wetlands (Ganzert et al., 2007; Jiang et al., 2010) where it is formed in the degradation of pectin or lignin (Schink and Zeikus, 1982; Ander and Eriksson, 1985). Through the production of methane, methanogenic archaea (methanogens) of northern peatlands have great significance for methane emissions to the atmosphere and with this for the global climate. Despite much relevant, our understanding on the response of microbial communities of the methane cycle to permafrost thaw is poor (Graham et al., 2011). Two recent studies conducted in a palsa ecosystem from Abisko, northern Sweden, traced methanogenic communities along the thawing of permafrost. There, a single methanogenic species of potentially hydrogenotrophic metabolism was identified as key driver for the formation of methane in a peat bog characterized by permafrost thaw (McCalley et al., 2014; Mondav et al., 2014). While these studies considered methane dynamics until palsa collapse, we aim at extending the knowledge on the methanogenic response to degrading permafrost tracking the methane cycle of an initial permafrost structure (palsa) along complete thaw until late peat bog succession. Assuming that the methanogenic response to permafrost thaw is reflected in alterations of community activity, abundance, and structure we determine these parameters in the light of detailed environmental analyses.

\section{Materials and Methods}

\section{Site Description and Field Work}

The study site was located in the Bøttemyra wetland in Finnmark (northern Norway). Three different geomorphological stages were selected for sampling and analyzing: a degrading palsa (DP; $\mathrm{N} 69^{\circ} 41.089$, E $29^{\circ} 11.951$ ), a thermokarst pond (TP; N 69 41.089 , E $\left.29^{\circ} 11.930\right)$ next to the degradation front of the palsa and a stabilized depression of a former collapsed palsa (CP; N $69^{\circ} 41.116$, E $\left.29^{\circ} 11.752\right)$. The TP site was characterized by a dense cover of both sedges and peat mosses while CP was dominated by peat mosses with sparse sedge cover. DP was mainly vegetated with Empetrum nigrum and Rhododendron tomentosum. All sampling sites were limited in nitrogen with high $\mathrm{C} / \mathrm{N}$ ratios as well as ammonium and nitrate concentrations below the detection limit (Liebner and Svenning, 2013). Field work and sampling was carried out in July 2011. Methane flux chamber and methane pore water measurements were additionally performed in July 2010.

\section{Soil Sampling}

Three biological replicates were sampled at each site. Sampling at the DP site was carried out using a stainless steel tube $(\varnothing$ $6 \mathrm{~cm}$ ) while the TP and CP sites were sampled by cutting three $20 \mathrm{~cm} \times 10 \mathrm{~cm}$ blocks out of the peat. Each $10 \mathrm{~cm}$ of a core/block was randomly sub-sampled down to $40 \mathrm{~cm}$ below the peat surface. All sub-samples from the same depth were combined, transferred into two $15 \mathrm{ml}$ sterile vials, and immediately shock frozen in liquid nitrogen $\left(\mathrm{N}_{2}\right)$ in the field. Long-term storage was at $-80^{\circ} \mathrm{C}$ until further processing.

\section{Environmental Parameters}

Pore water was collected in vertical profiles using small brass tubes as described elsewhere (Liebner et al., 2012). Two biological replicates were sampled. Conductivity, $\mathrm{pH}$, and dissolved oxygen were measured in the field using a multi parameter probe Multi 350i from WTW (Laboratory and Field Products, Nova Analytics). Air and peat temperatures were measured with a hand-held digital thermometer 2000T (Thermocouple Thermometer, Digitron Instrumentation Ltd, England) equipped with a $50 \mathrm{~cm}$ long probe. Organic acids (formate, acetate, butyrate) and ethanol were measured by HPLC as described previously (Metje and Frenzel, 2005). Water extractable DOC was determined as NPOC (non-purgable organic carbon) with the Shimadzu TOC-VCPH total organic carbon analyzer.

\section{Methane Flux, Pore Water Methane Concentrations, and Potential Methane Production}

Methane emissions of the field sites were measured in triplicate using plastic chambers sealed with a rubber stopper. The metal frames were pushed into the ground at least one day before the 
measurements to avoid collecting methane released from the soil during the installation. Water was used in the frames to seal off the chambers from ambient air. Gas chamber samples were collected with a syringe and directly transferred into evacuated $20 \mathrm{ml}$ glass vials. The sampling was done every $6 \mathrm{~min}$ for a total period of $30 \mathrm{~min}$. Pore water methane concentrations were measured in triplicates with the exception for site DP where only pore gas could be collected due to the dry conditions. The gas samples were stored in evacuated $20 \mathrm{ml}$ glass vials until analyzed.

Potential methane production from different depths was measured in triplicates. A sample of 6-10 g of soil was transferred to $50 \mathrm{ml}$ serum bottles and 2-10 $\mathrm{ml}$ of autoclaved water was added until water saturation was reached. The bottles were sealed with sterile butyl rubber stoppers, the head space was flushed with $\mathrm{N}_{2} / \mathrm{CO}_{2}(80: 20, \mathrm{v} / \mathrm{v})$ and the samples were incubated at $14^{\circ} \mathrm{C}$ in the dark. Potential $\mathrm{CH}_{4}$ production was additionally determined using $\mathrm{H}_{2} / \mathrm{CO}_{2}(80 / 20$ bar) and acetate $(20 \mathrm{mM})$ as substrates. Methane production in the headspace was measured daily for 5 days. All gas samples from the field and laboratory experiments were measured on a gas chromatograph (Agilent 6890 Series, Agilent Technology), and standard gasses were used for calibration.

\section{DNA Extraction, mcrA Gene Amplification, and Sequencing}

Soil nucleic acids were extracted in duplicates as described elsewhere (Liebner and Svenning, 2013). The samples were ground in liquid $\mathrm{N}_{2}$ to a fine powder. Approximately $0.3 \mathrm{~g}$ of sample was mixed with $0.5 \mathrm{ml}$ of extraction buffer (5\% cetyltrimethylammonium bromide [CTAB], $120 \mathrm{mMK}_{3} \mathrm{PO}_{4}[\mathrm{pH} 8]$ ) and subjected to bead beating for $45 \mathrm{~s}$. After phenol-chloroform extraction, nucleic acids were precipitated by incubation with linear acrylamide and 2 volumes of $30 \%$ polyethylene glycol 8000 (PEG-8000) for $120 \mathrm{~min}$ at room temperature, collected subsequently by centrifugation for $60 \mathrm{~min}$ at $4^{\circ} \mathrm{C}$, and resuspended in diethyl pyrocarbonate (DEPC)-treated water. Fragments of the mcrA gene were amplified using the mlas-mcrA-rev primer pair (Steinberg and Regan, 2008). PCR was carried out in duplicate $25 \mu \mathrm{l}$ reactions containing $12.5 \mu \mathrm{l}$ FailSafe PCR 2x PreMix F (Epicentre, Madison, WI, USA), $0.5 \mu$ l of each primer $(20 \mu \mathrm{M}), 1 \mathrm{U}$ Taq polymerase (Invitrogen, Carlsbad, CA, USA) and 0.5-1 $\mu 1$ 1:5 diluted DNA template, filled up with PCR-grade $\mathrm{H}_{2} \mathrm{O}$. Reaction conditions were as follows: initial denaturation at $95^{\circ} \mathrm{C}$ for $5 \mathrm{~min}, 32$ cycles with denaturation at $94^{\circ} \mathrm{C}$ for $30 \mathrm{~s}$, annealing at $55^{\circ} \mathrm{C}$ for $45 \mathrm{~s}$, extension at $72^{\circ} \mathrm{C}$ for $45 \mathrm{~s}$, and a final extension step at $72^{\circ} \mathrm{C}$ for $10 \mathrm{~min}$. PCR products were checked on a $1 \%$ agarose gel with ethidium bromide and purified using a QIAquick Gel Extraction Kit (Qiagen $\mathrm{GmbH}$, Germany). Clone libraries for the mcrA gene were established by ligating PCR products into the pCR 2.1-TOPO TA vector and transformed into competent cells Escherichia coli TOP10 using the TOPO TA Cloning Kit (Invitrogen) according to the manufacturer's protocol. White colonies were picked, re-suspended in LB medium containing ampicillin $\left(50 \mu \mathrm{g} \mathrm{ml}^{-1}\right)$ and grown overnight at $37^{\circ} \mathrm{C}$. Clones were screened by PCR with vector-specific M13 primers for the correct insert size and a total of 48 amplicons of each sample were sequenced by Macrogen (Amsterdam, Netherlands). The
Nucleotide sequences were analyzed with Sequencher (v4.7, Gene Codes, Ann Arbor, MI, USA).

\section{Bioinformatics and Statistics}

Nucleotide sequences were assigned into operational taxonomic units (OTUs) at a cutoff of 0.16 (Yang et al., 2014) using the furthest neighbor clustering method in MOTHUR (Schloss et al., 2009). Phylogenetic assignment and alignment of representative gene sequences was carried out using ARB (Ludwig et al., 2004) and a pre-configured mcrA database (http://www.mpimarburg.mpg.de/downloads/conrad/) that was updated using the CLC sequence viewer software package. The alignment was done using the integrated aligner with subsequent manual refinement. A neighbor-joining tree (Saitou and Nei, 1987) was constructed in ARB with a subset of $\sim 5200$ sequences including nearest neighbor and representative isolate sequences. Rarefaction curves were calculated using MOTHUR. The heatmap was constructed based on the OTU abundance table using pheatmap v0.7.4.

\section{Sequence Accession Numbers}

The sequences generated in this study have been deposited in the Genbank nucleotide sequence database under the accession numbers KJ603539 - KJ603857.

\section{Quantification of 16S rRNA, mcrA, and pmoA Gene Copies}

Quantitative real-time PCR (qPCR) was performed on a CFX96 ${ }^{\mathrm{TM}}$ cycler from Bio-Rad Laboratories using a SybrGreen assay. We enumerated universal bacteria, and universal archaea gene numbers based on the $16 \mathrm{~S}$ rRNA gene as well as methanogen and methanotroph genes ( $m c r A$ and $p m o A$, respectively). Each qPCR run included calibration standards and blanks and was performed in triplicates. Ahead of the final qPCR run, several sample dilutions were tested for potential inhibition. Mostly, a 1:100 dilution was sufficient to exclude inhibition while pronounced inhibition was observed at 1:10 dilutions. We used a final primer concentration of $0.4 \mu \mathrm{M}$ and $10 \mu \mathrm{L}$ SsoFast ${ }^{\mathrm{TM}}$ EvaGreen supermix (Bio-Rad Laboratories, CA, USA) in $20 \mu \mathrm{l}$ reactions. The specificity of each run was verified through melt-curve analysis and gel electrophoresis. Bacterial 16S rRNA genes were targeted with the primers Eub341F and Eub534R according to Degelmann et al. (2010) with annealing at $56^{\circ} \mathrm{C}$ for $20 \mathrm{~s}$. General archaeal $16 \mathrm{~S}$ rRNA genes were targeted with the primer combination A364 F (Burggraf et al., 1997) and A934 R (Großkopf et al., 1998) with annealing at $55.7^{\circ} \mathrm{C}$ for $25 \mathrm{~s}$. The $m c r A$ gene was amplified with the primers mlas and mcrA-rev (Steinberg and Regan, 2009) with annealing at $55^{\circ} \mathrm{C}$ for $20 \mathrm{~s}$ and $p m o A$ genes with the primer combination A189F and A682R (Holmes et al., 1995) with annealing at $60^{\circ} \mathrm{C}$ for $20 \mathrm{~s}$ and data acquisition at $78^{\circ} \mathrm{C}$ for melting of primer dimers. The potential amplification of nitrifiers using the primer combination A189F and A682R is unlikely given the pronounced limitation in nitrate and ammonium. Moreover, a previous study on methanotrophic community composition and gene expression from the same study sites did not identify any amoA like sequences using this primer combination (Liebner and Svenning, 2013). 


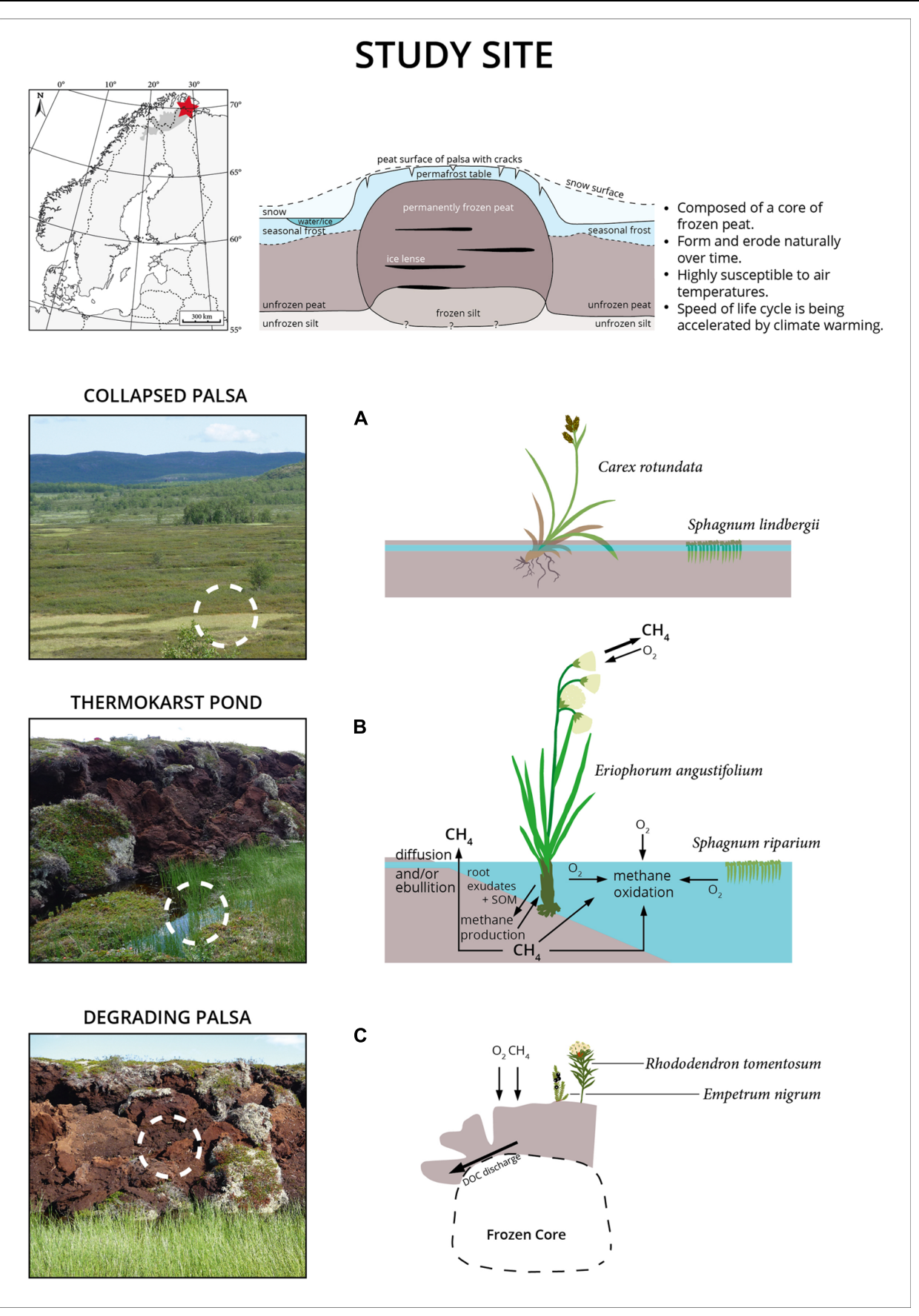

FIGURE 1 | Location of the study site in northern Norway in Finnmark county (top left), schematic cross section of a palsa (top right) modified from (Seppälä, 1986), and illustration of the sample sites. (A) Previous collapsed palsa site (CP) which has undergone permafrost degradation. (B) Thermokarst pond (TP) structures adjacent to currently degrading palsas (DP), and (C) DP. Note the changes in vegetation along palsa degradation and succession. Sphagnum riparium typically occurs in pioneer sites with constantly waterlogged conditions while Sphagnum lindbergii typically occurs at more stable sites with fluctuating water table.

\section{Results and Discussion}

\section{The Palsa Ecosystem}

Palsas are unique climate sensitive permafrost features of high latitude environments. The degradation of palsas leads to a successional gradient including shifts in hydrology, surface morphology, and plant species composition (Figure 1). Palsa collapse turned an elevated and dry site (DP) containing an intact ice core into a small freshwater system in the course of less than a decade. The evolving TP is colonized mainly by two plant species, 
the peat moss Sphagnum riparium, floating in large mats, and Eriophorum angustifolium/russeolum forming a dense cover of young vascular plants. Complete permafrost thaw and further peat bog succession led to the formation of the CP site, a stable stage within the succession of palsa peatlands. CP is water saturated with a surface layer that can seasonally dry out. Sphagnum lindbergii is the dominating plant species sparsely mixed with the sedge Carex rotundata. In situ temperatures were highest in the freshwater site (TP) where also seasonal temperature variations were low and complete freezing did not occur at any time during the year (data not shown). While pore water $\mathrm{pH}$ and conductivity varied little between the two water saturated sites TP and CP, more oxygen was on average dissolved in TP (Figure 2). Acetate was $362( \pm 91) \mu \mathrm{M}$ in $\mathrm{TP}$ and $472( \pm 252)$ $\mu \mathrm{M}$ in $\mathrm{CP}$ ( $n=10$ for both sites) and formate was $87( \pm 14)$ $\mu \mathrm{M}$ and $65( \pm 50) \mu \mathrm{M}(n=10$ for both sites), respectively. The fermentation products ethanol and butyrate were not detected. Acetate and formate concentrations were thus high compared with related studies (Ström et al., 2005; Whitmire and Hamilton, 2008; Liebner et al., 2012) and comparable with other acidic peatlands (Knorr et al., 2008; Küsel et al., 2008). It is well known that acetate accumulates in acidic peatlands although acetoclastic methanogenesis can occur simultaneously in association with plant roots (Bridgham et al., 2013). Also water extractable DOC was comparable between both wet sites although it should be highlighted that DOC values of the top layers of TP stuck out. In detail, DOC ranged between 85 (top) and 26 (bottom) $\mathrm{mg} \mathrm{L}^{-1}$ in the TP site, between 39 (top) and 27 (bottom) $\mathrm{mg} \mathrm{L}^{-1}$ in the CP site and between 40 (top) and 27 (bottom) $\mathrm{mg} \mathrm{L}^{-1}$ in the DP site. DOC values are thus much higher in this palsa ecosystem than in alpine (Liebner et al., 2012; McCalley et al., 2014) and arctic permafrost affected wetlands (King et al., 1998; Wagner et al., 2003) where values did not exceed $25 \mathrm{mg} \mathrm{L}^{-1}$. Likely, this results from permafrost thaw and DOC discharge in combination with low $\mathrm{pH}$ and water saturation limiting microbial decomposition. In fact, in a simple incubation experiment we observed no significant consumption of DOC in the course of 30 days in either of the sites (Supplementary Table S1) indicating low quality of the DOC.

The rapid palsa collapse was associated with the development of a dynamic methane cycle. While no methane emission occurred from the palsa itself, methane emission from TP had mean values of $340 \mathrm{mg}\left(\mathrm{CH}_{4}\right) \mathrm{m}^{-2} \mathrm{~d}^{-1}(n=9)$ with a pronounced spatial and temporal variation reflected in large standard deviations (Figure 3A). The fluxes of TP showed thereby notable maxima (up to $\sim 1 \mathrm{~g} \mathrm{~m}^{-2} \mathrm{~d}^{-1}$ ) but were on average
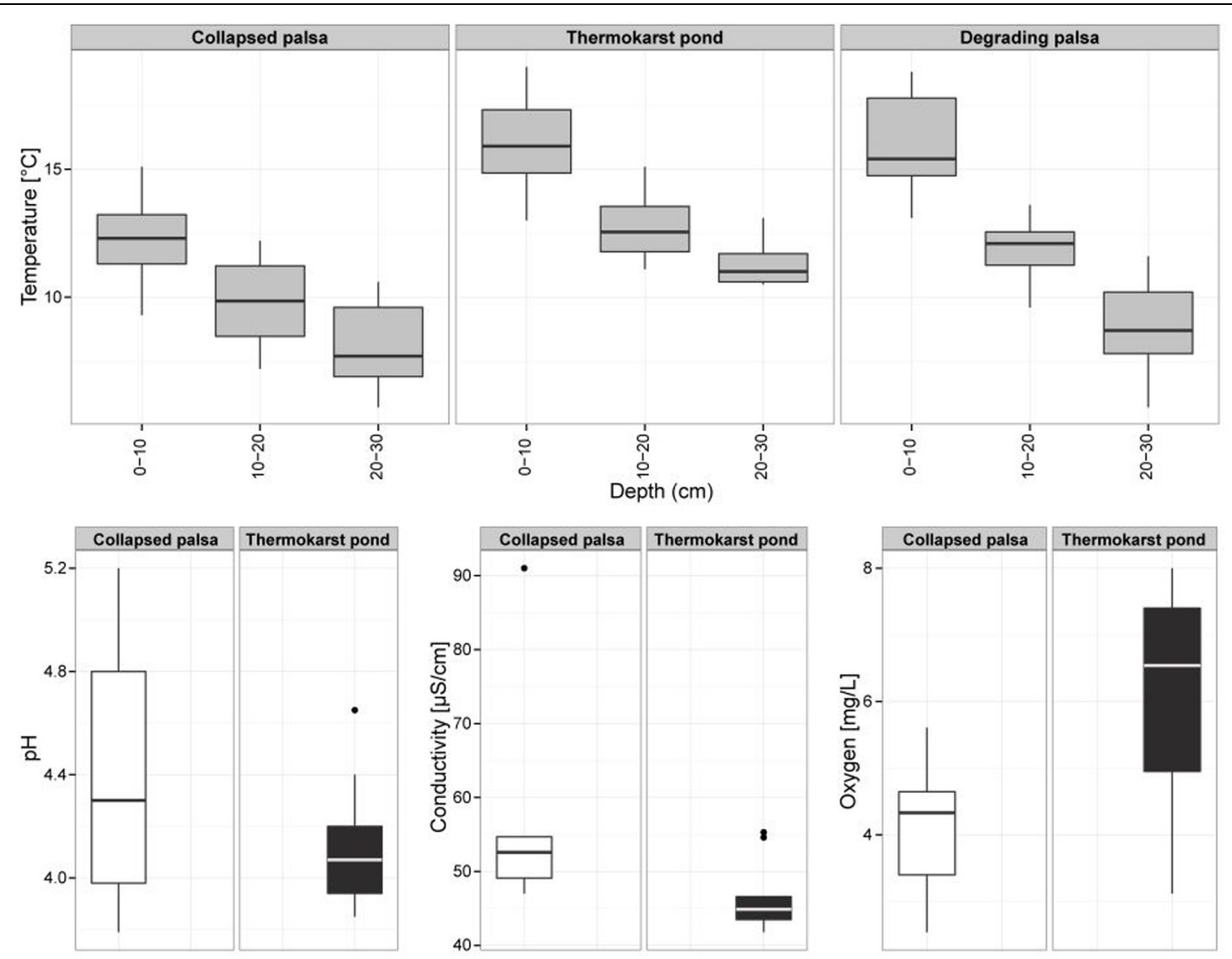

FIGURE 2 | Environmental parameters (temperature profiles, pH, conductivity, and dissolved oxygen) of the palsa sample sites. 
similar to fluxes from fens in the Alps and the Tibetan Plateau, from the Rocky Mountains, and from wet Arctic tundra (Liebner et al., 2012; and references therein). Toward CP, methane emissions decreased again with mean emissions of $\sim 63 \mathrm{mg}\left(\mathrm{CH}_{4}\right)$ $\mathrm{m}^{-2} \mathrm{~d}^{-1}(n=6)$ which is still higher than methane released from moderately wet Arctic tundra (Sachs et al., 2008; Wille et al., 2008). Methane concentrations in soil pore gas and pore water developed in accordance with the methane fluxes. While concentrations of methane in the palsa itself did not vary from atmospheric values, palsa collapse resulted in pronounced pore water methane concentrations in TP ranging from a mean of $48 \mu \mathrm{M}(n=12)$ in the uppermost $10 \mathrm{~cm}$ to a mean of $374 \mu \mathrm{M}(n=16)$ between 10 and $40 \mathrm{~cm}$ soil depth (Figure 3B). Toward CP methane concentrations also decreased reaching a mean value of $22 \mu \mathrm{M}(n=8)$ in the uppermost $10 \mathrm{~cm}$ and a mean of $202 \mu \mathrm{M}(n=11)$ between 10 and $40 \mathrm{~cm}$ soils depth. These values are also similar to related studies from northern and mountain wetlands (Liebner et al., 2012; and references therein).

Summarizing so far, palsa thaw initiates a fast development of intensive methane dynamics while further palsa peatland formation offers similarities with a typical transition from a minerotrophic fen to an ombrotrophic bog and the accompanied changes in methane dynamics (Whiting and Chanton, 1993; Hornibrook and Bowes, 2007). This transition is frequently observed to go along with a shift in methanogenic community structure and physiology from acetoclastic (often in combination with hydrogentrophic) to purely hydrogenotrophic methanogenesis and the accompanied decrease of $\delta^{13} \mathrm{C}$ methane values (Bridgham et al., 2013; McCalley et al., 2014). This shift potentially explains lower methane fluxes as a result of lower methane production efficiency through hydrogenotrophic methanogenesis compared with acetoclastic methanogenesis (Conrad, 1999).

\section{Methanogen Community Structure}

Our community data support the shift in methanogen pathways. We identified a methanogenic community clearly structured by both depth and habitat and shifts from a dominance of potential acetoclastic members in TP to a dominance of hydrogenotrophic members in $\mathrm{CP}$ (Figures $\mathbf{3 C}$ and $\mathbf{4 A - C}$ ). This shift from acetate to $\mathrm{H}_{2} / \mathrm{CO}_{2}$ as the main methanogenic substrate is supported by isotopic values of pore water methane with a $\delta^{13} \mathrm{C}$-methane of $-67.5 \%$ in TP and of $-80 \%$ in CP (Frenzel, personal information). Overall, we identified methanogens belonging to Methanosarcina, Methanobacterium, Methanocellales, and Methanoregula. The most abundant OTU_1 belongs to the genus Methanosarcina which can use a range of different precursors for methanogenesis. This OTU is representative for the only potentially acetoclastic 'species' in our study although we cannot exclude a methylotrophic pathway (Wagner et al., 2013). Thrives in TP in a depth of 10-30 cm characterized by Eriophorum roots. Eriophorum secretes high amounts of acetate compared to other vascular plants (Saarnio et al., 2004; Ström et al., 2005) and at the same time is suggested to prevent methane oxidation (Frenzel and Rudolph, 1998) either due to absent oxygen supply or massive release of organic acids in the rhizosphere.

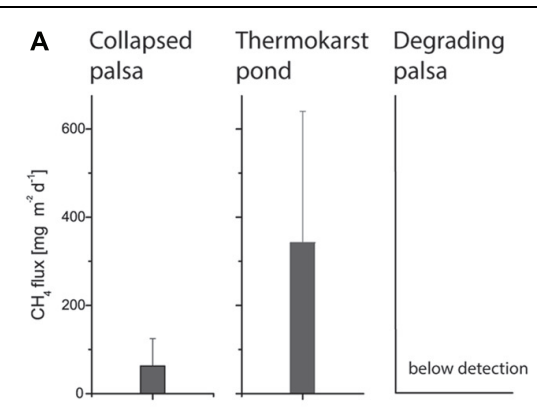

B
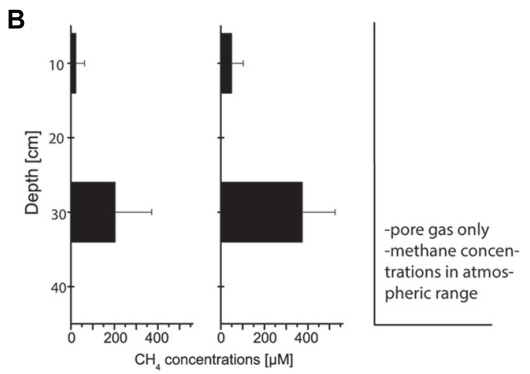

C

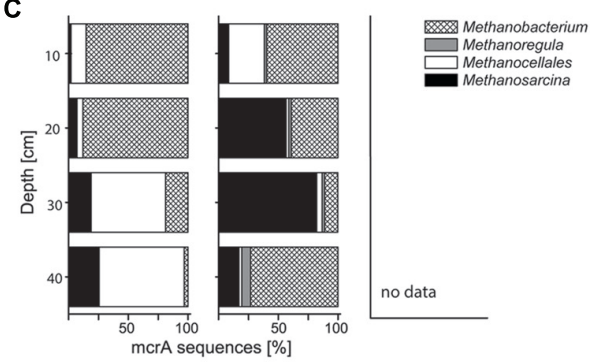

D
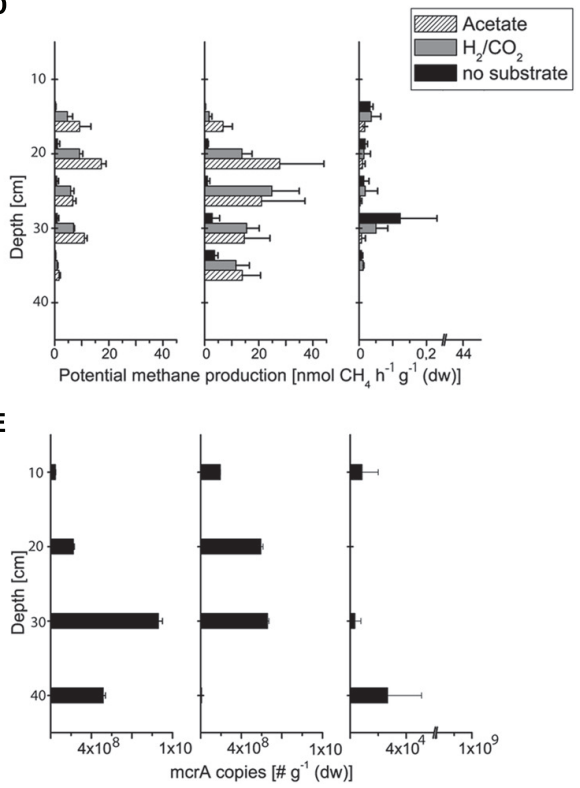

FIGURE 3 | Methane flux (A), pore water concentrations of methane (B), measured at two depths, 10 and $30 \mathrm{~cm}$, respectively, relative community composition of methanogenic archaea based on mcrA gene sequences (C), potential methane production from 15 to $25 \mathrm{~cm}$ depth (D), and the number of mcrA gene copies (E) from the different palsa sampling sites. 
Acetate was shown to inhibit methane oxidation in peatlands (Wieczorek et al., 2011; Kolb and Horn, 2012) and we also found no indication for methane oxidation in the layers of highest root density in the TP (data not shown). OTU_2 and OTU_3 belong to the hydrogenotrophic genus Methanobacterium sp. while OTU_4 is closely related to Candidatus 'Methanoflorens stordalenmirensis' which belongs to the former Rice Cluster I within the order Methanocellales and is suggested to use mainly $\mathrm{H}_{2} / \mathrm{CO}_{2}$ as substrate and energy source. This novel methanogen has recently been claimed as key methanogen in thawing permafrost although its biogeography points at a more global and diverse distribution (Conrad et al., 2010; Mondav et al., 2014). In the palsa ecosystem, OTU_4 thrives in the deeper parts of CP (20-40 cm, Figure 4B). OTU_5 related to Methanoregula, most likely hydrogenotrophic, too, was most abundant in the deeper parts of TP. Rarefaction analysis and OTU calculation indicate a very good coverage of the overall methanogenic diversity (Figure 4A) despite the rather low number of $\mathrm{mcrA}$ sequences. Next generation sequencing would certainly identify numerous rare taxa (less abundant than $1 \%$ ), however, the dominant methanogenic OTUs were identified. Our community analysis indicates that the palsa methanogenic community is thus not very diverse which is consistent to the recent work of Mondav et al. (2014) in a similar palsa environment. For each of the five most abundant OTUs we also screened the 500 closest hits in GenBank for their isolation source. In all cases there was a preference (OTU_1: 13/14; OTU_2:8/15; OTU_3: 9/17; OTU_4: 15/20; OTU_5: 18/22) toward organic rich, terrestrial habitats which overall points at a very specialized methanogenic community in palsa peatlands. Remaining OTUs had relatively few sequences with OTU_6 and 7 belonging to so far unclassified methanogens clustering with sequences from rumen. The presence of the latter could be due to reindeer grazing.
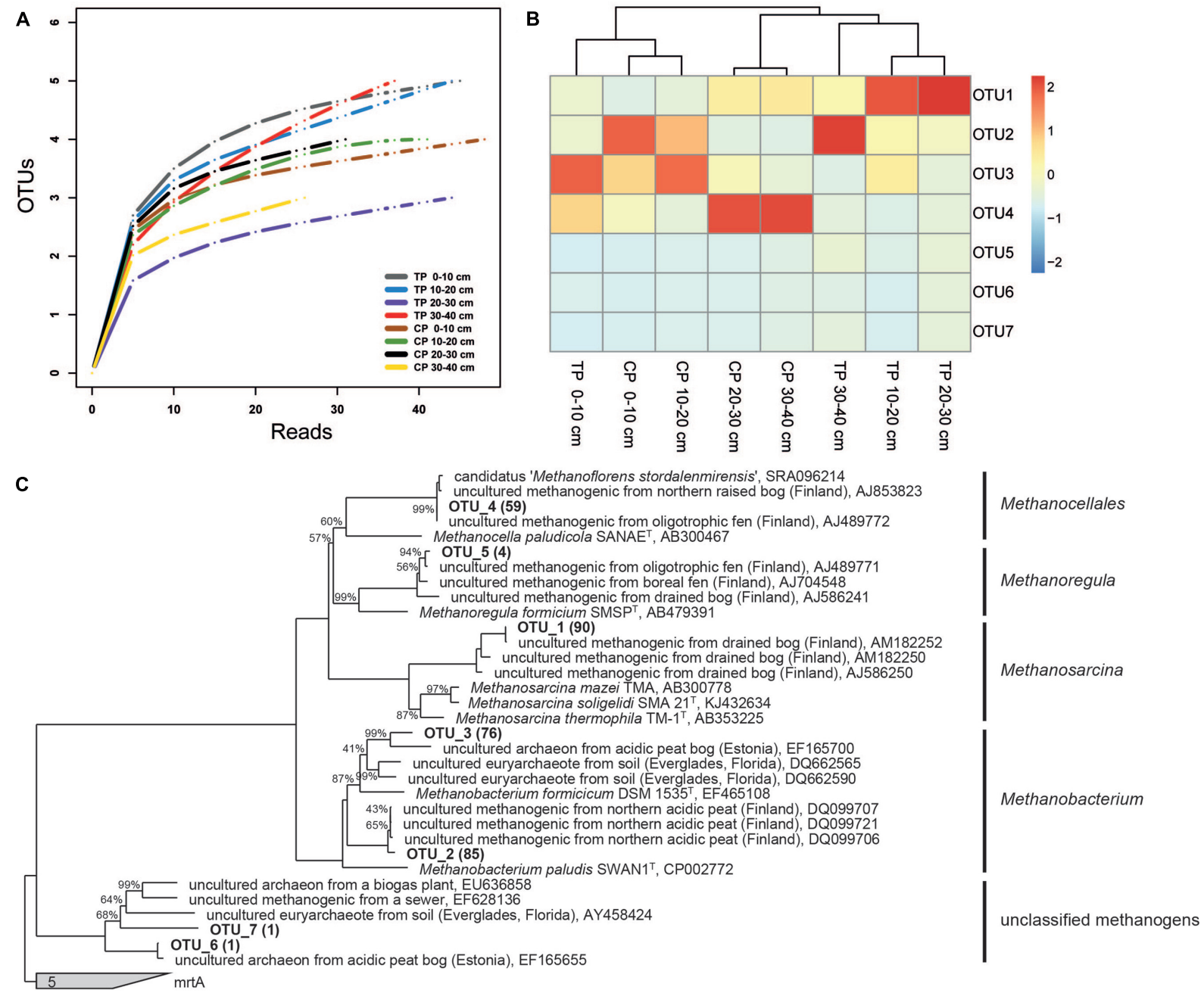

0.10

FIGURE 4 | Rarefaction curves (A), heatmap analysis (B), and phylogenetic tree (C) of $m c r A$ gene sequences from a sub-Arctic palsa wetland. In brackets the number of sequences that belong to each OTU. CP, collapsed palsa; TP, thermokarst pond. 


\section{Functional Gene Abundance}

Based on the enumeration of the mcrA gene as functional marker for methanogens we observed no significant differences in methanogenic abundance between TP and CP (Figure 3E, Supplementary Figures S1 and S2). Relating mcrA gene copy numbers to $16 \mathrm{~S}$ rRNA copy numbers of all archaea additionally shows that methanogens are dominant among the domain of archaea both in TP and in CP (Table 1). Also the abundance of methane oxidizers presented here as $p m o A$ gene numbers and in \% of $16 \mathrm{~S}$ rRNA gene copies of all bacteria does not significantly change along the two wet sites where methane oxidizers make up roughly $0.5 \%$ of the bacterial community. Nevertheless, the overall contribution of methanogens to methane emissions decreases which is also indicated based on potential rates of methane production (Figure 3D). Thus, our study highlights that methanogenic pathway and community structure is more important for soil methane concentrations and fluxes to the atmosphere than total abundance of methanogens and methane oxidizers.

\section{Conclusion}

The reason for the change from acetoclastic to hydrogenotrophic methanogenesis in the palsa ecosystem is not easily explained. Related studies attributed this shift to nutrient-poor acidic conditions in ombrogeneous bogs which typically result in a greater abundance of Sphagnum sp. and lower net $\mathrm{CH}_{4}$ emission rates compared to minerotrophic fens (Ström et al., 2005, 2012).
Sphagnum mosses in general produce organic compounds that are inhibitory for methanogenesis (Rooney-Varga et al., 2007). Fens possess a higher floral diversity, in particular, vascular vegetation, such as sedges and grasses that release labile carbon to soil via root exudates. Our data show that abundance of Sphagnum and sedges as well as nutrient regime and $\mathrm{pH}$ alone are insufficient to explain the observed shift in methanogenic community structure and methane fluxes. Both sites are grossly limited in nitrogen and $\mathrm{pH}$ values are even lower in the TP site. The amount of organic acids also varied only slightly. We conclude on a major influence of plant species composition on the methane fluxes along permafrost degradation and palsa peatland succession even though our approach is insufficient to provide final evidence on that. Both wet sites, TP and CP, are dominated by Sphagnum sp. and sedges, however, of different taxa. The two moss species, Sphagnum riparium and Sphagnum lindbergii, display differences in cation exchange capacity and the amount of soluble lignin with higher solubility in the case of Sphagnum lindbergii (unpublished data). Finally, in contrast to Carex sp., Eriophorum sp. appear to promote root associated acetoclastic methanogenesis while hampering methane oxidation.

\section{Acknowledgments}

We thank Erin C. Seybold for help during the field sampling. Fulbright Foundation is acknowledged for grant to Erin C. Seybold. LG was supported by 'Yggdrasil' stipend from The Research Council of Norway (210923). We thank Tove Midtun

TABLE 1 | Copy numbers of bacterial and archaeal 16S rRNA, methanogenic mcrA, and methanotrophic pmoA genes in three successional stages of a sub-Arctic palsa wetland.

\begin{tabular}{|c|c|c|c|c|}
\hline & 16S rRNA Bacteria ( $(\mathrm{SD})$ & 16S rRNA Archaea ( $\pm S D)$ & $\operatorname{mcr} A( \pm S D)$ & $p m o A( \pm S D)$ \\
\hline & \multicolumn{4}{|c|}{ Collapsed palsa (CP) } \\
\hline \multicolumn{5}{|c|}{ Depth (cm) } \\
\hline $0-10$ & $4.1 \times 10^{10} \pm 1.8 \times 10^{9}$ & $3.8 \times 10^{7} \pm 4.5 \times 10^{6}$ & $4.5 \times 10^{7} \pm 3.1 \times 10^{6}$ & $1.3 \times 10^{8} \pm 1.0 \times 10^{7}$ \\
\hline $10-20$ & $7.8 \times 10^{10} \pm 2.0 \times 10^{9}$ & $2.8 \times 0^{8} \pm 6.1 \times 10^{6}$ & $2.2 \times 10^{8} \pm 1.1 \times 10^{7}$ & $6.9 \times 10^{8} \pm 3.2 \times 10^{7}$ \\
\hline $20-30$ & $5.4 \times 10^{10} \pm 5.4 \times 10^{9}$ & $1.7 \times 10^{9} \pm 5.8 \times 10^{7}$ & $1.1 \times 10^{9} \pm 4.1 \times 10^{7}$ & $1.1 \times 10^{8} \pm 4.8 \times 10^{6}$ \\
\hline $30-40$ & $2.3 \times 10^{10} \pm 6.5 \times 10^{8}$ & $8.5 \times 10^{8} \pm 1.7 \times 10^{7}$ & $5.2 \times 10^{8} \pm 2.2 \times 10^{7}$ & $1.5 \times 10^{8} \pm 1.4 \times 10^{7}$ \\
\hline
\end{tabular}

Thermokarst pond (TP)

Depth (cm)

0-10

10-20

20-30

30-40

$$
\begin{aligned}
& 2.5 \times 10^{10} \pm 1.1 \times 10^{9} \\
& 1.9 \times 10^{10} \pm 3.2 \times 10^{8} \\
& 2.1 \times 10^{10} \pm 5.6 \times 10^{8} \\
& 1.0 \times 10^{9} \pm 1.4 \times 10^{7}
\end{aligned}
$$

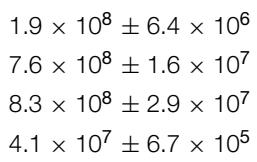

$$
\begin{aligned}
& 1.9 \times 10^{8} \pm 3.0 \times 10^{6} \\
& 5.9 \times 10^{8} \pm 2.3 \times 10^{7} \\
& 6.6 \times 10^{8} \pm 1.3 \times 10^{7} \\
& 8.5 \times 10^{6} \pm 1.6 \times 10^{6}
\end{aligned}
$$

$4.0 \times 10^{8} \pm 1.3 \times 10^{7}$
$1.1 \times 10^{8} \pm 7.0 \times 10^{6}$
$2.6 \times 10^{7} \pm 2.0 \times 10^{6}$
n.d.

Degrading palsa (DP)

Depth (cm)

$\begin{array}{ll}0-10 & 7.4 \times 10^{8} \pm 2.6 \times 10^{7} \\ 10-20 & 2.1 \times 10^{9} \pm 9.2 \times 10^{7} \\ 20-30 & 4.0 \times 10^{8} \pm 2.1 \times 10^{6} \\ 30-40 & 2.3 \times 10^{9} \pm 1.2 \times 10^{7}\end{array}$

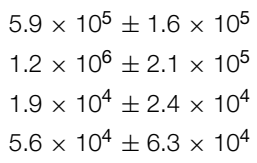

$8.3 \times 10^{3} \pm 1.2 \times 10^{4}$

n.d.

$3.2 \times 10^{3} \pm 4.5 \times 10^{3}$

$2.7 \times 10^{4} \pm 2.4 \times 10^{4}$
$7.0 \times 10^{5} \pm 2.0 \times 10^{4}$
$1.7 \times 10^{6} \pm 3.7 \times 10^{4}$
$9.1 \times 10^{5} \pm 4.7 \times 10^{4}$
$2.2 \times 10^{6} \pm 2.6 \times 10^{5}$

n.d. - not determined.

Values are mean $\pm S D, N=6$ and refer to gram of dry soil. 
for assistance with figure design and preparation. The study, as part of the European Science Foundation EUROCORES Programme EuroEEFG, project MECOMECON, was funded through The Research Council of Norway (Grant 201270/V40), and Tromsø Research Foundation.

\section{References}

Ander, P., and Eriksson, K. -E. (1985). Methanol formation during lignin degradation by Phanerochaete chrysosporium. Appl. Microbiol. Biotechnol. 21, 96-102. doi: 10.1007/BF00252369

Barbier, B. A., Dziduch, I., Liebner, S., Ganzert, L., Lantuit, H., Pollard, W., et al. (2012). Methane-cycling communities in a permafrost-affected soil on Herschel Island, Western Canadian Arctic: active layer profiling of mcrA and pmoA genes. FEMS Microbiol. Ecol. 82, 287-302. doi: 10.1111/j.15746941.2012.01332.x

Bridgham, S. D., Cadillo-Quiroz, H., Keller, J. K., and Zhuang, Q. (2013). Methane emissions from wetlands: biogeochemical, microbial, and modeling perspectives from local to global scales. Global Change Biol. 19, 1325-1346. doi: $10.1111 /$ gcb. 12131

Burggraf, S., Huber, H., and Stetter, K. O. (1997). Reclassification of the crenarchaeal orders and families in accordance with $16 \mathrm{~S}$ rRNA sequence data. Int. J. Syst. Bacteriol. 47, 657-660. doi: 10.1099/00207713-47-3-657

Christensen, T. R., Johansson, T. R., Akerman, H. J., Mastepanov, M., Malmer, N., Friborg, T., et al. (2004). Thawing sub-arctic permafrost: effects on vegetation and methane emissions. Geophys. Res. Lett. 31:L04501. doi:10.1029/2003GL018680

Conrad, R. (1999). Contribution of hydrogen to methane production and control of hydrogen concentrations in methanogenic soils and sediments. FEMS Microbiol. Ecol. 28, 193-202. doi: 10.1111/j.1574-6941.1999. tb00575.x

Conrad, R., Klose, M., Claus, P., and Enrich-Prast, A. (2010). Methanogenic pathway, $13 \mathrm{C}$ isotope fractionation, and archaeal community composition in the sediment of two clear-water lakes of Amazonia. Limnol. Oceanogr. 55, 689-702. doi: 10.4319/lo.2009.55.2.0689

Degelmann, D. M., Borken, W., Drake, H. L., and Kolb, S. (2010). Different atmospheric methane-oxidizing communities in European beech and Norway Spruce Soils. Appl. Environ. Microbiol. 76, 3228-3235. doi: 10.1128/AEM.02730-09

Frank-Fahle, B. A., Yergeau, É., Greer, C. W., Lantuit, H., and Wagner, D. (2014) Microbial functional potential and community composition in permafrostaffected soils of the NW Canadian Arctic. PLOS ONE 9:e84761. doi: 10.1371/journal.pone.0084761

Frenzel, P., and Rudolph, J. (1998). Methane emission from a wetland plant: the role of CH4 oxidation in Eriophorum. Plant Soil 202, 27-32. doi: 10.1023/A:1004348929219

Ganzert, L., Jurgens, G., Munster, U., and Wagner, D. (2007). Methanogenic communities in permafrost-affected soils of the Laptev Sea coast, Siberian Arctic, characterized by $16 \mathrm{~S}$ rRNA gene fingerprints. FEMS Microbiol. Ecol. 59, 476-488. doi: 10.1111/j.1574-6941.2006 00205.x

Graham, D. E., Wallenstein, M. D., Vishnivetskaya, T. A., Waldrop, M. P., Phelps, T. J., Pfiffner, S. M., et al. (2011). Microbes in thawing permafrost: the unknown variable in the climate change equation. ISME J. doi: 10.1038/ismej. 2011.163

Großkopf, R., Janssen, P. H., and Liesack, W. (1998). Diversity and Structure of the methanogenic community in anoxic rice paddy soil microcosms as examined by cultivation and direct $16 \mathrm{~S}$ rRNA gene sequence retrieval. Appl. Environ. Microbiol. 64, 960-969.

Hofgaard, A. (2004). Etablering av overvåkingsprosjekt på palsmyrer. NINA Oppdragsmelding 841, 32.

Holmes, A. J., Costello, A., Lidstrom, M. E., and Murrell, J. C. (1995). Evidence that particulate methane monooxygenase and ammonia monooxygenase may be evolutionarily related. FEMS Microbiol. Lett. 132, 203-208. doi: 10.1111/j.15746968.1995.tb07834.x

\section{Supplementary Material}

The Supplementary Material for this article can be found online at: http://journal.frontiersin.org/article/10.3389/fmicb.2015.00356/ abstract

Hornibrook, E. R. C., and Bowes, H. L. (2007). Trophic status impacts both the magnitude and stable carbon isotope composition of methane flux from peatlands. Geophys. Res. Lett. 34, 1-5. doi: 10.1029/2007GL0 31231

IPCC. (2007). Contribution of Working Group I to the Fourth Assessment Report of the Intergovernmental Panel on Climate Change, 2007. Cambridge: Cambridge University Press.

Jiang, N., Wang, Y., and Dong, X. (2010). Methanol as the primary methanogenic and acetogenic precursor in the cold zoige wetland at tibetan plateau. Microb. Ecol. 60, 206-213. doi: 10.1007/s00248-009-9602-0

King, J. Y., Reeburgh, W. S., and Regli, S. K. (1998). Methane emission and transport by arctic sedges in Alaska: results of a vegetation removal experiment. J. Geophys. Res. 103, 29083-29092. doi: 10.1029/98JD00052

Knorr, K. H., Glaser, B., and Blodau, C. (2008). Fluxes and ${ }^{13} \mathrm{C}$ isotopic composition of dissolved carbon and pathways of methanogenesis in a fen soil exposed to experimental drought. Biogeosciences 5, 1457-1473. doi: 10.5194/bg-5-1457 2008

Kolb, S., and Horn, M. A. (2012). Microbial $\mathrm{CH}_{4}$ and $\mathrm{N}_{2} \mathrm{O}$ consumption in acidic wetlands. Front. Microbiol. 3:78. doi: 10.3389/fmicb.2012.00078

Kotsyurbenko, O. R., Friedrich, M. W., Simankova, M. V., Nozhevnikova, A. N. Golyshin, P. N., Timmis, K. N., et al. (2007). Shift from acetoclastic to h2dependent methanogenesis in a west siberian peat bog at low ph values and isolation of an acidophilic methanobacterium strain. Appl. Environ. Microbiol. 73, 2344-2348. doi: 10.1128/AEM.02413-06

Küsel, K., Blöthe, M., Schulz, D., Reiche, M., and Drake, H. L. (2008) Microbial reduction of iron and porewater biogeochemistry in acidic peatlands. Biogeosciences 5, 1537-1549. doi: 10.5194/bg-5-1537-2008

Liebner, S., Schwarzenbach, S., and Zeyer, J. (2012). Methane emissions from an alpine fen in central Switzerland. Biogeochemistry 109, 287-299. doi: $10.1007 / \mathrm{s} 10533-011-9629-4$

Liebner, S., and Svenning, M. M. (2013). Environmental transcription of mmoX by methane oxidizing Proteobacteria in a Sub-Arctic palsa peatland. Appl. Environ. Microbiol. 79, 701-706. doi: 10.1128/AEM.02292-12

Ludwig, W., Strunk, O., Westram, R., Richter, L., Meier, H., Yadhukumar, Buchner, A., et al. (2004). ARB: a software environment for sequence data. Nucl. Acids Res. 32, 1363-1371. doi: 10.1093/nar/gkh293

Luoto, M., and Seppälä, M. (2003). Thermokarst ponds as indicators of the former distribution of palsas in Finnish Lapland. Permafrost Periglacial Process. 14, 19-27. doi: 10.1002/ppp.441

McCalley, C. K., Woodcroft, B. J., Hodgkins, S. B., Wehr, R. A., Kim, E. -H., Mondav, R., et al. (2014). Methane dynamics regulated by microbial community response to permafrost thaw. Nature 514, 478-481. doi: 10.1038/nature13798

Metje, M., and Frenzel, P. (2005). Effect of temperature on anaerobic ethanol oxidation and methanogenesis in acidic peat from a Northern Wetland. Appl. Environ. Microbiol. 71, 8191-8200. doi: 10.1128/AEM.71.12.8191-8200.2005

Metje, M., and Frenzel, P. (2007). Methanogenesis and methanogenic pathways in a peat from subarctic permafrost. Environ. Microbiol. 9, 954-964. doi: 10.1111/j.1462-2920.2006.01217.x

Mondav, R., Woodcroft, B. J., Kim, E. -H., Mccalley, C. K., Hodgkins, S. B., Crill, P. M., et al. (2014). Discovery of a novel methanogen prevalent in thawing permafrost. Nat. Commun. 5, 3212. doi: 10.1038/ncomms4212

Nauta, A. L., Heijmans, M. M. P. D., Blok, D., Limpens, J., Elberling, B., Gallagher, A., et al. (2014). Permafrost collapse after shrub removal shifts tundra ecosystem to a methane source. Nat. Clim. Change 5, 67-70. doi: $10.1038 /$ nclimate 2446

Rooney-Varga, J. N., Giewat, M. W., Duddleston, K. N., Chanton, J. P., and Hines, M. E. (2007). Links between archaeal community structure, vegetation type and methanogenic pathway in Alaskan peatlands. FEMS Microbiol. Ecol. 60, 240-251. doi: 10.1111/j.1574-6941.2007.00278.x 
Saarnio, S., Wittenmayer, L., and Merbach, W. (2004). Rhizospheric exudation of Eriophorum vaginatum L. - Potential link to methanogenesis. Plant Soil 267, 343-355. doi: 10.1007/s11104-005-0140-3

Sachs, T., Wille, C., Boike, J., and Kutzbach, L. (2008). Environmental controls on ecosystem-scale $\mathrm{CH}_{4}$ emission from polygonal tundra in the Lena River Delta, Siberia. J. Geophys. Res. 113, G00A03. doi: 10.1029/2007JG000505

Saitou, N., and Nei, M. (1987). The neighbor-joining method: a new method for reconstructing phylogenetic trees. Mol. Biol. Evol. 4, 406-425.

Schink, B., and Zeikus, J. G. (1982). Microbial ecology of pectin decomposition in anoxic Lake Sediments. J. Gen. Microbiol. 128, 393-404. doi: 10.1099/00221287128-2-393

Schloss, P. D., Westcott, S. L., Ryabin, T., Hall, J. R., Hartmann, M., Hollister, E. B., et al. (2009). Introducing mothur: open-source, PlatformIndependent, Community-Supported Software for Describing and Comparing Microbial Communities. Appl. Environ. Microbiol. 75, 7537-7541. doi: 10.1128/AEM.01541-09

Schuur, E. A. G., Bockheim, J., Canadell, J. G., Euskirchen, E., Field, C. B., Goryachkin, S. V., et al. (2008). Vulnerability of permafrost carbon to climate change: implications for the global carbon cycle. Bioscience 58, 701-714. doi: 10.1641/B580807

Seppälä, M. (1986). The Origin of Palsas. Stockholm: Swedish Society for Anthropology and Geography.

Serreze, M. C., and Francis, J. A. (2006). The arctic amplification debate. Clim. Change 76, 241-264. doi: 10.1007/s10584-005-9017-y

Serreze, M. C., Walsh, J. E., Chapin, F. S., Osterkamp, T., Dyurgerov, M., Romanovsky, V., et al. (2000). Observational evidence of recent change in the northern high-latitude environment. Clim. Change 46, 159-207. doi: 10.1023/A:1005504031923

Steinberg, L. M., and Regan, J. M. (2008). Phylogenetic comparison of the methanogenic communities from an acidic, oligotrophic fen and an anaerobic digester treating municipal wastewater sludge. Appl. Environ. Microbiol. 74, 6663-6671. doi: 10.1128/AEM.00553-08

Steinberg, L. M., and Regan, J. M. (2009). mcrA-targeted real-time quantitative pcr method to examine methanogen communities. Appl. Environ. Microbiol. 75, 4435-4442. doi: 10.1128/AEM.02858-08

Ström, L., Mastepanov, M., and Christensen, T. (2005). Species-specific effects of vascular plants on carbon turnover and methane emissions from Wetlands. Biogeochemistry 75, 65-82. doi: 10.1007/s10533-004-6124-1

Ström, L., Tagesson, T., Mastepanov, M., and Christensen, T. R. (2012). Presence of Eriophorum scheuchzeri enhances substrate availability and methane emission in an Arctic wetland. Soil Biol. Biochem. 45, 61-70. doi: 10.1016/j.soilbio.2011.09.005

Tarnocai, C., Canadell, J. G., Schuur, E. A. G., Kuhry, P., Mazhitova, G., and Zimov, S. (2009). Soil organic carbon pools in the northern circumpolar permafrost region. Global Biogeochem. Cycles 23:GB2023. doi: $10.1029 / 2008$ GB003327
Thauer, R. K. (1998). Biochemistry of methanogenesis: a tribute to Marjory Stephenson:1998 Marjory Stephenson Prize Lecture. Microbiology 144, 2377-2406. doi: 10.1099/00221287-1449-2377

Victor, D. G., Zhou, D., Ahmed, E. H. M., Dadhich, P. K., Olivier, J. G. J., Rogner, H.-H., et al. (2014). "Introductory chapter," in Climate Change 2014: Mitigation of Climate Change. Contribution of Working Group III to the Fifth Assessment Report of the Intergovernmental Panel on Climate Change, IPCC, eds O. Edenhofer, R. Pichs-Madruga, Y. Sokona, E. Farahani, S. Kadner, K. Seyboth, et al., (Cambridge, NY: Cambridge University Press).

Wagner, D., Kobabe, S., Pfeiffer, E. -M., and Hubberten, H. -W. (2003). Microbial controls on methane fluxes from a polygonal tundra of the Lena delta, Siberia. Permafrost and Periglac Process 14, 173-185. doi: 10.1002/ ppp.443

Wagner, D., Schirmack, J., Ganzert, L., Morozova, D., and Mangelsdorf, K. (2013). Methanosarcina soligelidi sp. nov., a desiccation and freeze-thaw resistant methanogenic archaeon isolated from a Siberian permafrost-affected soil. Int. J. Syst. Evolu. Microbiol.

Whiting, G. J., and Chanton, J. P. (1993). Primary production control of methane emission from Wetlands. Nature 364, 794-795. doi: 10.1038/364 $794 \mathrm{a} 0$

Whitmire, S., and Hamilton, S. (2008). Rates of anaerobic microbial metabolism in wetlands of divergent hydrology on a glacial landscape. Wetlands 28, 703-714. doi: 10.1672/06-126.1

Wieczorek, A. S., Drake, H. L., and Kolb, S. (2011). Organic acids and ethanol inhibit the oxidation of methane by mire methanotrophs. FEMS Microbiol. Ecol. doi: 10.1111/j.1574-6941.2011.01080.x

Wille, C., Kutzbach, L., Sachs, T., Wagner, D., and Pfeiffer, E. -M. (2008). Methane emission from Siberian arctic polygonal tundra: eddy covariance measurements and modeling. Global Change Biol. 14, 1395-1408. doi: 10.1111/j.13652486.2008.01586.x

Yang, S., Liebner, S., Alawi, M., Ebenhöh, O., and Wagner, D. (2014). Taxonomic database and cut-off value for processing $m c r A$ gene 454 pyrosequencing data by MOTHUR. J. Microbiol. Methods 103, 3-5. doi: 10.1016/j.mimet.2014. 05.006

Conflict of Interest Statement: The authors declare that the research was conducted in the absence of any commercial or financial relationships that could be construed as a potential conflict of interest.

Copyright (c) 2015 Liebner, Ganzert, Kiss, Yang, Wagner and Svenning. This is an open-access article distributed under the terms of the Creative Commons Attribution License (CC BY). The use, distribution or reproduction in other forums is permitted, provided the original author(s) or licensor are credited and that the original publication in this journal is cited, in accordance with accepted academic practice. No use, distribution or reproduction is permitted which does not comply with these terms. 